\title{
Teaching English Compound Noun Stress
}

\author{
Yvon-Pierre Ndongo Ibara ${ }^{1}$, Roland Giscard Ondze Otouba ${ }^{1} \&$ Jules Bianchiny Ossere Mounguellet ${ }^{1}$ \\ ${ }^{1}$ Université Marien N'GOUABI, Congo \\ Correspondence: Yvon-Pierre Ndongo Ibara, Université Marien N'GOUABI, Congo
}

Received: December 12, 2018 Accepted: January 20, 2019 Online Published: January 23, 2019

doi: 10.5539/elt.v12n3p46 URL: https://doi.org/10.5539/elt.v12n3p46

\begin{abstract}
The aim of this research paper is to scrutinize the teaching of English pronunciation based on English compound noun stress at secondary school. In fact, the teaching of compound noun stress has not been highlighted by previous scholars. In addition, teaching strategies based on this item have not been taken into account by INRAP and E.N.S in the course of phonetics and phonology. As a result, no teacher is able to teach compound noun stress and no learner is able to practice this language item. Therefore, our practical suggestions are made of teaching and learning strategies, a set of exercises and a sample of a teaching card to encourage teachers to deal with compound noun stress. This study is an attempt to show the parallel between the techniques of teaching of reading and that of compound noun stress.
\end{abstract}

Keywords: teaching, learning, compound noun, English, pronunciation

\section{Introduction}

The teaching and learning of English language are solely characterised by the top priority of grammar course adjoined by reading comprehension when the pronunciation remains a poor parent (Note 1). This teaching policy leads most English learners to be orally poor performers in non-English speaking countries. In recent literature (Ndongo Ibara 2015, 2016, Ondze Otouba 2015, 2016, Akariki 2018, etc.), there is a new tendency advocating the teaching of pronunciation to reinforce English language learning. In this respect, sounds, words, phrases, and sentences receive a particular attention. Similarly, this paper discusses English compound noun teaching. It addresses the following questions (i) How relevant is it to teach compound noun stress? (ii) Can we teach compound English stress the same way we teach tenses in English? Can we evaluate English noun stress like reading comprehension?

This paper is made of three sections; the first shows the relevance of teaching English compound word stress, the second demonstrates the way English compound noun stress can be taught, finally, evaluation is dealt with in section three.

\section{The Relevance of Teaching Pronunciation}

At secondary school, learners find English sounds very difficult because they are not familiarized with this language sound system. They naturally think that it is impossible to catch them up. Martinez-Flor et al. (2006), Aliaga Garcia (2007), Yolanda Joy Calvo Benzies (2013: 4) argues that:

English pronunciation is considered to be one of the most difficult skills to acquire and develop. This may be due to a number of factors, e.g. the irregular correspondence between spelling and pronunciation and the impact of the learning process of factors such as age, motivation and amount of exposure to the L2.

Since learners are not motivated by teachers on the study of English sounds, they, unfortunately, prefer to focus on other language items such as grammar lessons, reading comprehension, for their examinations (Note 2). In fact, talking about the teaching of English sounds refers to the importance of this latter on the teaching and learning process of English language in the Congolese secondary schools. For, taught and learnt as a foreign language, the study of sounds in English must be taken into account since it enables both teachers and learners to know how to pronounce English words correctly, to be familiarized with the English sound systems and avoid misunderstanding each other during the classroom interaction. This is what Harire (2012) quoted by Calvo Benzies (Ibid) writes that: The importance of sounds for effective communication means that foreign language teachers need to emphasize pronunciation teaching in their classes. Whence the pronunciation of the different sounds making a word are well processed in the mind of the learner, he feels more comfortable to pronounce the 
word. This hypothesis is emphasized by Lee and Van Patten (op. cit.:38),

Acquisition consists in large part of the building up of form-meaning connections in the learner's head. For example, the learner of French hears the word chien in various contexts and eventually attaches it to a particular meaning: a four-legged canine. As another example, a learner of Italian might hear -ato in various contexts and eventually attach it to a particular meaning: a past-time reference. Features of language, be they grammar, vocabulary, pronunciation, or something else, can only make their way into the learner's mental representation of the language system if they have been linked to some kind of real-world meaning. If the input is incomprehensible or if it is not meaning-bearing, then these form-meaning connections just don't happen.

Besides, concerning the learners' lack of motivation towards the English course and the focus on some language items, just, for their examinations, the teaching of English sounds aims to develop the learners' competence, confidence and improve the learners' level of proficiency in spoken English. For this reason, Liang-chen Lin (2014: 16) states that:

Many of English language learners (ELLs) confront difficulties in learning English pronunciation. Problems in pronunciation weaken their communicative competence (...) More precisely, it is necessary that teachers develop their awareness on diverse sound structures.

In other words, in case of teaching and learning English language process, the study of English sounds helps teachers in terms of self-motivation and self-esteem. This is because when we want to talk in English language, the most important thing that we require is confidence. Thus, if the English teachers master how words are produced and how they are pronounced correctly, it would raise their confidence to speak in English. Besides, it would help teachers to develop their confidence level in front of their learners while they are teaching and speaking in English. Peter Roach $(2009,6)$ argues:

No pronunciation course that I know has ever said that learners must try to speak perfect RP; to claim this mixes up models with goals: the goal chosen is RP but the goal is normally to develop the learners' pronunciation sufficiently to permit effective communication with native speakers.

In other words, Peter Roach demonstrates that it is not the role of the pronunciation course to force learners speak like native, but rather to enable them to speak in such a way that they can interchange with native speakers. Thus, the pronunciation course will give them the correct pronunciation of words by distinguishing British from American English too. For example, the words "lieutenant", in which the letters "lieu", in British English are pronounced [lef] whereas in American English we pronounce [lu:], "exude", in which the letters "exu", in British English are pronounced [Igzju:] whereas in American English we pronounce [Igzu:], and "extrinsici", in which the letter "s", in British English is pronounced [z] but in American English we pronounce [s]. That is the reason why Murat (2009, 1697) evidences: Pronunciation teaching is a significant part of foreign language teaching. Since sounds play an important role in communication, foreign language teachers must attribute proper importance to teaching pronunciation in their classes.

\section{The Relevance of Teaching English Compound Noun Stress}

It would be pointless to deal with the importance of teaching English pronunciation items without painting every aspect that contribute to the negligence of this course. To begin with, let us mention the teachers' incapacity to deal with the teaching/learning process of compound word stress at secondary school is due to the lack of background information regarding such a teaching.

Table 1. Teaching English word stress

\begin{tabular}{lcc}
\hline Have you been trained to teaching English word stress? \\
\hline Yes & 01 & $25 \%$ \\
No & 04 & $75 \%$ \\
\hline
\end{tabular}

(Based on Mounguellet Ossere, 2017:39).

This assertion means, teachers lack training in the teaching/learning process of compound word stress at the secondary school. They have been taught phonetics and phonology scientifically for their own interests, without considering the didactic aspects or how to teach pronunciation courses at secondary school in taking into account all the different parts of the teaching card (beginning, presentation, practice, production and ending). Phonetics and phonology as a university course has only been a profit to teachers themselves in the way that it has helped 
them increase their knowledge regarding the English language sound system and the English phonetic and phonological system in terms of teacher improvement. They should have known about sound description in terms of places and manners of articulation, but they have certainly not succeeded to transform scientific knowledge to learning knowledge.

Moreover, further to a question asked to the five (05) teachers of English, we have found out that workshops on the teaching/learning process methodologies on compound words stress in the secondary school have never been organized by INRAP (Note 3).

Table 2. INRAP Workshop organization

\begin{tabular}{lll}
\hline Does INRAP organise workshop? & & \\
\hline Yes & 00 & $0 \%$ \\
No & 05 & $100 \%$
\end{tabular}

(Based on Mounguellet Ossere, op.cit. 40).

This accounts for INRAP policy which, though requiring the teaching of word stress in the secondary school, is not able to equip teachers with appropriate methodologies on how to deal with compound word stress as a pronunciation course in the secondary school. That is the reason why a lot of teachers think that compound word stress teaching/learning process should be done or mixed with reading comprehension sessions or with grammar lessons during which they occasionally utter some compound words without any insistence or showing the stress patterns. In addition, most teachers teach compound word stress at random; some teachers make learners repeat any compound word they encounter while reading a text; others transcribe phonetically the compound words then make learners repeat. It is obvious that teachers lack strategies in the matter of teaching compound word stress as a pronunciation course in the secondary schools.

Furthermore, according to the majority of English language teachers, compound word stress has never been taught at any school and is not important regarding learners training. This because, compound word stress has never been parts of practical exercises programmed during classwork or exams such as the General Certificate of Education "O level", General Certificate of Education "A level" or other national or international competitions where English is programmed as one of the disciplines.

We have also noticed another factor hampering the English teaching/learning process, that of the school environmental realities. As a matter of fact, English is taught in almost a hostile environment where conditions do not permit both teachers and learners practice English compound words stress.

Table 3. Study environment

\begin{tabular}{lll}
\hline Is the learning environment suitable? & \\
\hline Yes & 01 & $25 \%$ \\
No & 05 & $75 \%$ \\
\hline
\end{tabular}

(Based on Mounguellet Ossere, op.cit: 44).

Finally, we cannot end up these observations without mentioning the teacher's disabilities in the matter of creating procedures and strategies that can fit the learning of English compound word stress in the secondary school. Though the majority of teachers confess not to have been trained how to teach word stress during their academic stay, but, it is worth mentioning the teacher should be audacious and creative. That is to say, the teacher is a person who is able to create appropriate teaching strategies and adapts the learning materials according to learner's age and level in order to make them grasp and master the materials to be taught. Here, the teacher should simplify and demystify through effective teaching strategies basing on a teaching card the learning materials then put them successfully at the disposal of learners.

In the light of the above findings, it is obvious that learners' disabilities regarding spoken English is justified. In other words, teachers' disabilities to create procedures in order to teach compound word stress as a pronunciation course affects learners proficiency in the matter of speaking English as a second language learning. That is to say, 
if learners are not able to express themselves in English orally, it is due to the fact that they have only acquired grammatical competence for examination, but they lack communicative competence to practice what they have learnt. This aspect justifies the reason why learners are able to write in English but are unable to read the materials they write then speak English fluently. They are mainly trained on activities such as True or False statements, written questions answering, Blank filling and to mention but only a few which are activities they especially encounter during class tests and exams. Hence, learners remain weaker in spoken English than in written English from the beginning till the end of their study in the secondary school. The above assertion is corroborated by Abbas Pourhosein Gilakjani (2016, p. 3) when he argues that:

Many teachers are not aware of the importance of pronunciation. Teachers pay enough attention to grammar and vocabulary in learning a foreign language and they help learners become skillful in listening and reading. Secondly, the majority of teachers think that pronunciation study is too difficult and monotonous for learners.

We have mainly found out learners incapacity to speaking English fluently so far as regarding spoken English, their competence and performance remain weak from the beginning till the end of their study in the secondary school. This implies not only both INRAP and teachers' responsibility regarding the English language teaching process, more precisely about pronunciation courses but, does it also imply university' responsibility.

Moreover, we have found out that the English courses is realised in a bad environment. In other words, English is practiced in non-appropriate conditions because of the lack of equipment, laboratories and electricity to enable learners follow oral materials and practice compound word stress. In the same token, classrooms are too overcrowded and noisy and do not facilitate the practice of pronunciation courses.

Finally, we have underlined teachers' disabilities in the matter of creating procedures or teaching strategies in order to make learners grasp and master compound words stress then practice them successfully inside of the classroom at first and out of the classroom at last.

Whether the stress of a single word can be dictated according to its nature, its morphological form or the number of its syllable, that of a compound requires much more refinement. The teaching of compound nouns falls in the teaching of compound words in English. Fudge (1984, p. 134) asserts that compounds:

are the combination of words that may occur independently elsewhere, and hence must be two words; at the same time, they are combined in such a way that they form a single relatively close-nit whole with a number of characteristics that indicate rather clearly that they are one word.

Whence words are combined, they lose their initial phonetic property and are assigned new phonetic patterns based on their new identity. Renner (2006, p. 11) says:

L'étude des mots composés est un domaine de recherche qui ne cesse de susciter une abondante littérature, probablement parce que les descriptions et les analyses présentées ne sont jamais totalement satisfaisantes, du fait de la grande complexité du phénomène. La littérature spécialisée est souvent jalonnée de mises en garde quant aux difficultés qui attendent le linguiste.

In the lines of Renner, it appears that compounds are so complex that it is not always easy to deal with them. So, the study of English compound word stress can become an easy concern thanks to the teaching process which aims to "eliminate everything difficult from language teaching and learning" at secondary school (Roach: 2009). That is, the teacher should provide various teaching strategies that can facilitate the learning process of this item in classes. In other words, if learners do not benefit from the teaching of compound words, there will be a strong tendency to pronounce compounds based on its initial status. The teaching and learning strategies are made by taking into account the different stages of the teaching card such as: beginning, presentation, practice, production and ending. Thus, the teacher uses various procedures mastered during the training period in order to make learners understand and practice compound word stress either orally or in written activities. In addition, the teacher aims to make learners be familiar with the way to utter compound words without difficulties. In this perspective, Peter Roach (2009) adds:

Pronunciation activity may be difficult of course, but if we eliminate everything difficult from language teaching and learning, we may end up a little beyond getting students playing simple communication games.

It is obvious that the teacher needs to be creative and audacious in order to set suitable activities that can help learners grasp and master the course of compound word stress. In this connection, Dilza Borges and Beatriz Lessa (1996: 1) say:

Developing tasks for teaching English sounds requires creativity and audacity because we need to know how to make these sounds interesting for students. In fact, depending on the way we present English sounds to students, 
it can be very boring and discouraging for them.

It is evident that learners face difficulties in the practice of English compound word stress. But, if the teacher can create and develop appropriate learning activities about this linguistic item, learners can surely find this issue interesting.

\section{Teaching English Compound Noun Stress}

According to the Communicative Language teaching (henceforth CLT), teaching a language aims to develop communicative competence which, in the words of Canale and Swain (1980, p. 4), encompasses four components:

i. grammatical competence: words and rules

ii. sociolinguistic competence: appropriateness

iii. discourse competence: cohesion and coherence

iv. strategic competence: appropriate use of communication strategies

Next, the lesson layout shows three phases namely:

\section{i. Pretask activity}

ii. Task cycle

\section{iii. Language focus.}

The Pretask activity is compared to warming time to a sportsman. During this time, the teacher's job is to facilitate learners to understand the theme or the topic they are exposed to for the purpose of communication.

The second step includes three elements: Task, Planning and Report. In fact, the Task is about pushing learners to make effort to raise spontaneity. The teacher monitors, encourages, tutors, but does not intervene regarding slips of tongue, syntax or grammar.

Planning is an intermediate period when learners draft what they are going to produce, reports in front of others. The role of the teacher is to advice, suggest, help and polish the draft to meet some language standards.

Report is the time when some learners report their work when others listen purposefully so that they can comment the story. During this task, the teacher tactfully chairs, comments, and rephrases.

The Language Focus phase includes Analysis and Practice. The Analysis is about some controlled tasks teacher asks to do based on a piece of writing or recordings. This task can bear on vocabulary, grammar, and semantics. The flows of information starts with the teachers and ends up with the learners. Something can written on board for memory. The last of the lesson is practice when learners helped by the teachers practice the lesson or the notions taught individually or in group. Activities include choral repetition, memory game, sentence completion, matching up, multiple choice, and rearrangement.

As things stand, it is obvious that the CLT matches up with teaching language functions. Yet, one should remember that, according to Bloom's verb taxonomy, verbs like 'analyse' necessitates a certain degree of thinking sensitive to school grades. Much more, one cannot practice a language unless they master its sound patterns. In this connection, no communication can occur where and when language rudiments, that is, sounds, are not mastered by the speaker-hearer. This corroborates the babbling step during language acquisition.

We believe that the CLT method cannot fit with the teaching of the pronunciation of the sounds of a given language. This is the reason why, we resort to $P-P-P$ cycle instead. We can explain the three Ps in the following lines. The first part of this section is devoted to the presentation of the different parts of a teaching card, while the second part shows the different steps when teaching English compound nouns based on a teaching card. In addition to the three Ps, there are a beginning and an evaluation phases.

\subsection{Beginning}

In the beginning, the teacher greets learners then asks them the day's date. After this step, the teacher deals with the pre-requisites step using some tasks to find out if learners are familiar with compound nouns. After, they select noun/noun compounds to teach as the day's lesson.

\subsection{Presentation}

The teacher provides a list of noun/noun compounds together with the explanation on their stress. In addition, while learners are following, the teacher explains some rules on how to stress noun/noun compounds and gives learners a task. 


\subsection{Practice}

The teacher asks learners to read noun/noun compounds written on the board and then provide their own examples orally.

\subsection{Production}

The teacher asks learners to write their own noun/noun compounds on the board with stress marker and pronounce them.

\subsection{Evaluation}

The teacher provides a task and asks learners to identify categories of noun/noun compounds from a word list. At the end, the teacher gives learners a homework. Evaluation is a set of exercises based on compound nouns stress that the teacher uses to reinforce learner's understanding in this language item at secondary school.

When teaching a noun-noun compound, the teacher should bear in mind that steps refer to specific objectives to be achieved. The general objective being to pronounce noun compounds correctly in English.

To begin with, the first specific objective is let learners be able to identify an English compound noun based on its morphology, form. Fudge (op.cit. p. 135) claims that

very frequently one and the same compound can be written in more than one fashion with no loss of acceptability: ice cream, ice-cream, and icecream are all to be found, as are colour blind, colour-blind, and colourblind, match box, match-box, and matchbox.

In this respect, based on stress, the following group of words does not share the same nature: The White House and $\boldsymbol{A}$ White House. The first group refers to a compound noun because it is the name of the place where the President of US lives, whereas the second is a phrase denoting the colour of a house.

Next, the second specific objective is to permit learners to get the meaning of the compound. In this respect, the teacher clarifies the notion of compound noun to the learners saying that it is about some nouns which denote species, kinds of, a category of, while others represent people, brands, etc. In this connection, we can distinguish between a bread knife and a Smart phone. In the first case, we are concerned with a kind of knife that we use with bread. But the second is a brand, the name of telephone. As this is a didactic process, it is useless to talk about endocentric compound (toothbrush) and exocentric compound (Redskin) since the two terms are more technical to learners.

Further to the meaning, the teachers provide learners with the stress patterns of compound nouns in English in a didactic way. There follows a sample of a teaching card on the teaching of compound noun stress in English with upper sixth form learners as the target population.

Level: Terminale A

Subject: English

Matter: pronunciation

Title of the lesson: Compound noun Stress in English

G.O.2: Expressing oneself orally

S.O.1.1: Stressing English compound words

Teacher:

Performance objective

\section{TEACHING CARD $\mathrm{N}^{\circ} 1$}

Attendance: 55

G: 35 ; B: 20

Date: Thursday, May $12^{\text {th }} 2017$

Duration: $30 \mathrm{~min}$

Reference books: Phonetics and Phonology: A Resource Book for Teaching English complex words stress, Peter Roach 


$\begin{array}{ll}\text { illustrate compound } & \text { the word list: } \\ \text { nouns in English } & \text { handball, } \\ & \text { blackboard, world } \\ & \text { cup, dancing club }\end{array}$

At the end of this lesson section, the learner should be able to identify compound nouns based on the teacher's explanations.

\section{DAILY LESSON}

Title: Compound Noun stress

\section{Presentation}

In English, we have noun/noun compounds written in one word, in two words, or with a hyphen such as bedroom, water tank, motorcycle/

The teachers adds

At the end of this lesson section, the learner should be able to stress compound nouns correctly
When a compound is composed of two nouns, the stress falls on the first noun.

bedroom, ice-cream, motorcycle

\section{When a noun compound written in two nouns and can become a verb, the stress is put on the second noun.}

mass-producer, underline, toothbrush

\section{Practice}

The teacher asks learners to read compound nouns written on the board and provide their own examples orally.

\section{Production}

The teacher asks learners to write their own compound nouns on the board and pronounce them

\section{Evaluation}

The teacher asks learners to stress compound noun in in the following

word list: handball,

dancing club, underline,

blackboard, black

door, grey hair
Learners follow the teacher's

demonstration and listen to his pronunciation carefully.

Learners practice with the teacher's while others listen then they practice amongst themselves.

Learners follows instruction and write their own words.

Learners follow and do the task carefully.

\section{Task 2:}

Read the noun/noun compounds written on the blackboard and provide your own examples orally.

\section{Task 3:}

Write your own noun/noun compounds on the board and pronounce them.

Task 4: Identify compound nouns in the following word list: police 


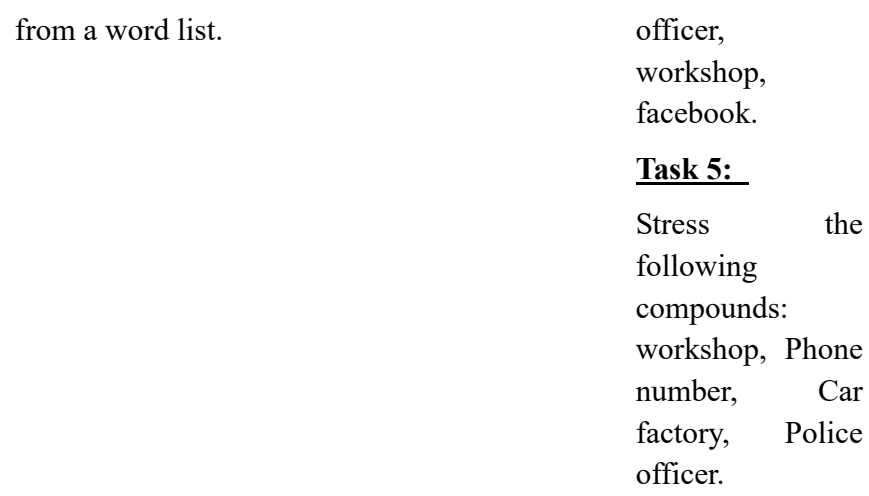

\section{The Evaluation of English Compound Noun Stress}

In teaching, everything taught must be evaluated. In this connection, compound noun stress can also be evaluated in the lines of ordinary tasks school learners face during exam such as True or False, Matching. Here are examples of pronunciation tasks parallel to the teaching of reading comprehension.

Task 1: Multiple choice

Choose between (a) or (b) which one matches up with the stress of the word.

1. Phone number

$$
\begin{array}{lll}
1 & 2 & \text { (a)- First part }
\end{array}
$$

(b)- Second part

2. Primary school
12
(a)-First part
(b)-Second part

3. Boarding $\underline{\underline{\text { school }}}$
12
(a)-First part
(b)-Second part

4. News paper
12
(a)-First part
(b)-Second part

5. Academic year
12
(a)-First part
(b)-Second part

6. Come over
12
(a)-Second part
(b)-First part

Task 2: Say whether the stress (') of the following word is True or False.

1. 'Police station

2. Air'plane

3. 'Understanding

4. Rain'fall

5. 'Haircut

6. soft'ware

\section{Conclusion}

This paper advocates the teaching of pronunciation focusing on the stress of compound nouns in English. In fact, 
it comes out that pronunciation can be compared to grammar since it has subcomponents which can be taught like articles, tenses, number, and agreement. These pronunciation aspects concern sound teaching (Ndongo Ibara, 2015, 2016; Ondze, 2015, 2016; Akariki, 2018; Mvouomo, 2018) and stress and intonation teaching (Lamy Nkoukou, 2016; Massala Mfoutou, 2018). Like grammar items or reading comprehension task, these pronunciation items are so complex that their mastery deserves enough attention for a better didactic contract. If we agree with Pourhosein Gilakjani Abbas, (Op. cit, p. 5) when he argues that

Pronunciation instruction is very important because it is the main source of understanding. If learners cannot utter the correct version of a word then they are not able to communicate correctly. Pronunciation instruction helps learners to have a better understanding of native speakers and improves their ability to communicate easily and effectively.

but we have to add that communication purpose attached to language teaching and learning should be reinforced by pronunciation skill for a better didactic input. If other language issues (i.e. language functions) can be taught based on CLT approach, pronunciation course should be based on P-P-P-cycle. Let's conclude with Dominique Abry and Julie Veldeman-Abry (2007, p. 7).

Après avoir été mis de côté par la première génération des approches communicatives, on assiste à un retour en force de la correction phonétique en classe de langue. En effet, la compétence de communication, que ce soit en compréhension de l'oral ou en production orale, repose sur une série de distinctions phonologiques sur lesquelles vont s'élaborer des distinctions grammaticales et lexicales. Une prononciation erronée peut gêner la compréhension d'un message car souvent il n'y a qu'un son qui porte la distinction. La qualité de l'échange en dépend. On imagine aisément l'incompréhension et la confusion entre deux interlocuteurs dont l'un s'entend dire «Dites-moi tout» alors que l'autre voulait dire «Dites-moi tu!».

\section{Reference}

Abry, D., \& Julie Veldeman-Abry. (2007). Phonétique, Paris, CLÉ.

AKariki, N. (2017). Teaching English diphthongs at secondary school: A case study of Première classes at Lycée de la Révolution, ENS, Université Marien N'Gouabi, Brazzaville.

Aliaga, G. C. (2007). The Role of Phonetic Training in L2 Speech Learning. Proceedings of the Phonetics Teaching and Learning Conference (PTLC2007), University College, London.

Calvo Benzies, Y. J. (2013) Spanish EFL University students' views on the teaching of pronunciation: A survey-based study. Language studies Working Papers, 5, 41-49.

Canale, M., \& Swain, M. (1980). Theoretical Bases of Communicative Approaches to Second Language Teaching and Testing. Applied Linguistics, 1(1), 1-47. https://doi.org/10.1093/applin/I.1.1

Celece-Murcia, M. (1995). Teaching pronunciation: A reference for Teachers of English to Speakers of Other Languages. Cambridge: CUP

Fudge, E. (1984). English Word Stress, London: George Allen \& UNWIN.

Hymes, D. (1972). On communicative competence. In J. B. Pride, \& J. Holmes, (Eds.), Sociolinguistics, Harmondsworth. England: Penguin Books.

Kumaravadivelu, H. (1994). The postmethod condition: (E)merging strategies for second/foreign language teaching. TESOL Quarterly, 28(1), 27-48. https://doi.org/10.2307/3587197

Lamy Nkounkou, R. H. (2016). Teaching English word stress: An analysis of disyllabic words in the class of Terminale A at Chaminade high school, ENS, Université Marien N'Gouabi, Brazzaville.

Larsen-Freeman, D. (1986). Techniques and Principles in Language Teaching. Oxford: Oxford University Press.

Lee, J. F., \& Bill van Patten. (1995). Making Communicative Language Teaching Happen. New York: McGraw-Hill

Liang, C. L. (2014). Understanding Pronunciation variations facing ESL students. International Journal of Humanities and Social sciences, 4(5), 16-20.

Luu, T. M. V. (2009). Compound Words in English and Vietnamese, 1-10.

Marguerite, A. (1997). Les pédagogies de l'apprentissage, PUF.

Martínez-Flor, A., Usó-Juan, E., \& Alcón Soler, E. (2006). Towards Acquiring Communicative Competence through Speaking. In E. Usó-Juan, \& A. Martínez-Flor (Eds.), Current Trends in the Development and Teaching of the Four Language Skills (pp. 139-157). Berlin: Mouton de Gruyter. https://doi.org/10.1515/ 


\subsubsection{9}

Massala Mfoutou, D. U. (2017). Teaching English dissylabic noun stress at secondary school: A case study of Première D class at Chaminade high school, ENS, Université Marien N'Gouabi, Brazzaville.

Murat, H. (2009). The pronunciation of the inter-dental sounds of English: An articulation problem for Turkish learners of English and solutions. Procedia Social and Behavioral Sciences, 1, 1697-1703. https://doi.org/10.1016/j.sbspro.2009.01.301

Mvouomo, F. A. (2017). Teaching English triphthongs at secondary school: A Case study of Terminale classes at Lycée de la Révolution, ENS, Université Marien N'Gouabi, Brazzaville.

Ndongo-Ibara, Y. P. (2015). Framing English sound-letter parallelism teaching. Revue Francophone Liens, Nouvelles séries, 20, 37-47.

Ndongo-Ibara, Y. P. (2016). An Empirical Review of English Language Teaching in Congo. Studies in English Language Teaching, 400-415. https://doi.org/10.22158/selt.v4n4p400

Ondze, O. R. G. (2015). Teaching English Sounds in Secondary School, ENS, Université Marien N'Gouabi, Brazzaville.

Ondze, O. R. G. (2016). L'enseignement de la prononciation des voyelles simples dans les classes de Première au Congo, ENS, Université Marien N'Gouabi, Brazzaville.

Ossere, M. J. B. (2017). Teaching English Compound word Stress: an Analysis of Compound Nouns in the Class of 'Terminale A' at Lycée de la Réconciliation, ENS, Université Marien N'Gouabi, Brazzaville.

Pierret, J. J. (2010). Developing Materials for Teaching Word Stress in English, Muncie, Indiana: Ball States University.

Pourhosein Gilakjani A. (2016). English Pronunciation Instruction: A Literary review. International Journal of Research in English Education, 1-6.

Renner, V. (2006). Les composés coordinatifs en anglais contemporain. Doctoral dissertation, Lyon, Université de Lyon 2 Lumière.

Richards, J. C. (2006). Communicative Language Teaching Today. Cambridge: Cambridge University Press.

Richards, J. C., \& Rodgers, T. S. (1986). Approaches and Methods in Language Teaching. Cambridge: Cambridge University Press.

Roach, P. (1998). English phonetics and Phonology (2nd ed.). Cambridge: CUP.

Skehan, P. (1996). Second language acquisition research and task-based instruction. In J. Willis, \& D. Willis (Eds.). Challenge and Change in Language Teaching. Oxford: Heinemann.

Sreehari, P. (2012). Communicative Language Teaching: Possibilities and Problems. English Language Teaching, 87-93. https://doi.org/10.5539/elt.v5n12p87

Wesche, M. B., \& Skehan, P. (2002). Communicative, task-based, and content-based language instruction. In R. B. Kaplan (Ed.), Oxford handbook of Applied Linguistics (pp. 207-228).

\section{Notes}

Note 1. In Communicative language teaching, four types of competences are advocated: linguistic competence, sociolinguistic competence, discourse competence and strategic competence (Larsen-Freeman, 1986, Canale \& Swain, 1980, Celce Muria et al., 1996, Hymes, 1972, Richards, 2006, Richards \& Rodgers, 1986, Wesche \& Skehan, 2002, Kumaravadivelu, 1994, Pusuluri Sreehari, 2012 ...) and. The first competence includes vocabulary, grammar, pronunciation, etc. If we agree with Lee and Van Patten (1995) that "The learner must be able to understand most of what the speaker (or writer) is saying if acquisition is to happen. [. . .], the learner must be able to figure out what the speaker is saying if he is to attach meaning to the speech stream coming at him" we should admit that effective communication also depends on pronunciation.

Note 2. In the Republic of Congo, oral examination is banned in secondary education system.

Note 3. Institut National de Recherches et d'Action Pédagogique. This institute is in charge of in training service and curricula elaboration 


\section{Copyrights}

Copyright for this article is retained by the author(s), with first publication rights granted to the journal.

This is an open-access article distributed under the terms and conditions of the Creative Commons Attribution license (http://creativecommons.org/licenses/by/4.0/). 